\title{
Transfusi Albumin dan Furosemid pada Sindrom Nefrotik Anak dengan Edema
}

\author{
Meita Dwi Utami, Taralan Tambunan \\ Departemen Ilmu Kesehatan Anak Fakultas Kedokteran Universitas Indonesia/RS Dr. Cipto Mangunkusumo, Jakarta
}

Latar belakang. Pemberian albumin pada anak dengan sindroma nefrotik (SN) serta edema dapat meningkatkan tekanan osmotik dan menarik cairan ekstraselular kembali ke dalam kompartemen vaskular sehingga mengurangi edema. Namun, beberapa penelitian terhadap pasien dewasa mendapatkan bahwa mekanisme intrarenal bertanggung jawab terhadap retensi air sehingga pemberian albumin hanya akan memberikan efek minimal pada pasien SN dengan edema, selain dapat berpotensi menyebabkan kelebihan (overload) cairan Tujuan. Mengetahui penggunaan albumin bersama loop diuretik (furosemid) dapat menurunkan risiko terjadinya edema dibandingkan dengan penggunaan tunggal loop diuretik pada anak dengan sindrom nefrotik

Metode. Penelusuran pustaka database elektronik, yaitu Pubmed, Cochrane, Proquest

Hasil. Terdapat 4 penelitian yaitu 1 kohort prospektif, 2 penelitian uji klinis, serta 1 telaah sistematik mendapatkan pemberian diuretik saja aman dan efektif meningkatkan diuresis dibandingkan dengan kombinasi albumin-diuretik. Pemberian furosemid dan albumin pada pasien SN dengan edema harus sesuai kondisi klinis per pasien, pemberian terapi kombinasi dapat dipertimbangkan pada pasien yang resisten diuretik.

Kesimpulan. Pemberian albumin dan furosemid bukan merupakan prosedur rutin pada setiap pasien SN dengan edema dan hipoalbuminemia. Secara statistik, terapi kombinasi diuretik dan natriuretik ini masih dianggap tidak bermakna. Sari Pediatri 2017;18(6):498-503

Kata kunci: sindrom nefrotik, albumin, furosemide, diuresis

\section{Albumin and Furosemid Transfusion in Patients with Nephrotic Syndrome Children with Edema}

\author{
Meita Dwi Utami, Taralan Tambunan
}

Background. The routine use of albumin for severe edema in children with NS is based on severe hypoalbuminemia decreases intravascular oncotic pressure, leading to circulatory volume depletion and subsequent sodium/water retention. Study in adults showed overfill mechanism proposes a primary renal defect in sodium excretion leading to sodium/water retention and thereby hypervolemia and edema. Albumin give a minimal effect and has potentially effect of an overload.

Objective. To know beneficial effect of albumin and furosemide combination therapy in decreasing risk of edema, compared to diuretic therapy alone in children with nephrotic syndrome.

Method. Literature search using electronic data base Pubmed, Cochrane, Proquest.

Result. There were 4 researches consist of 1 prospective cohort, 2 clinical trials and 1 systematic review which showed that diuretic alone was save and effective in increasing diuresis compare to albumin-diuretic combination. Combination of albumin-diurestic in NS with edema should be given not routinely and can be consider in patient with diuretic resistant.

Conclusion. Diuretic therapy alone is safe in pediatric patients with NS presenting with edema and hypoalbuminemia. Statistically showed that diuretic and natriuretic effect by combination albumin-furosemide was not significant. Sari Pediatri 2017;18(6):498-503

Keywords: nephrotic syndrome, albumin, furosemide, diuresis

Alamat korespondensi: Dr. Meita Dwi Utami, Prof. Dr. Taralan Tambunan, Tambunan,SpA(K). Departemen Ilmu Kesehatan Anak Fakultas Kedokteran Universitas Indonesia/RS Dr. Cipto Mangunkusumo, Jakarta. Email: taralan_fkui@yahoo.com 
$\mathrm{P}$ emberian albumin intravena telah diketahui sebagai salah satu metode yang efektif sebagai tata laksana edema pada pasien sindrom nefrotik (SN). Hal ini berbeda dengan pasien SN dewasa yang jarang mendapatkan transfusi albumin, pasien anak lebih sering diberikan albumin intravena karena tingginya angka pelaporan resisten diuretik, terdapatnya penurunan efikasi diuretik, meningkatnya diuresis ketika diuretik diberikan setelah albumin intravena. ${ }^{1,2}$

Pemberian rutin albumin pada pasien anak SN karena edema yang berat didasarkan pada dua hipotesis yang berhubungan dengan patogenesis edema yaitu teori "underfill" dan "overfill". Teori "underfill" menyatakan bahwa hipoalbuminemia berat mengakibatkan tekanan onkotik intravaskular menurun sehingga terjadi deplesi volume sirkulasi dan pada akhirnya akan menyebabkan retensi air. ${ }^{3}$ Sedangkan mekanisme "overfill" didasarkan pada defek renal primer terutama pada ekskresi sodium yang menyebabkan terjadinya retensi sodium/air dan pada akhirnya mengakibatkan hypervolemia dan edema. ${ }^{3,4}$ Pasien SN anak seringkali menunjukkan gejala klinis hipovolemia, sehingga pemberian infus albumin dapat meningkatkan tekanan osmotik dan menarik cairan ekstraselular kembali ke dalam kompartemem vaskular sehingga edema dapat berkurang.

Saat ini belum terdapat panduan khusus pemberian albumin pada pasien anak dengan sindrom nefrotik. Laporan kasus berbasis bukti kali ini bertujuan untuk mengetahui efektivitas pemberian albumin guna mengurangi terjadinya edema pada pasien anak dengan sindrom nefrotik.

\section{Kasus}

Seorang anak lelaki berusia 17 tahun 10 bulan, berat badan $90 \mathrm{~kg}$, datang ke rumah sakit dengan keluhan bengkak sejak 3 hari sebelumnya. Pasien telah didiagnosis sindrom nefrotik sejak 3 tahun yang lalu, rutin kontrol ke poliklinik RS dan dalam terapi rumatan metilprednisolon $12 \mathrm{mg}$, lisinopril, angioten dan amlodipin. Pada pemeriksaan fisis didapatkan edema anasarka, status respirasi dan hemodinamik stabil, dari pemeriksaan penunjang darah dalam batas normal kecuali kadar albumin serum menunjukkan hipoalbuminemia (albumin 1,56 $\mathrm{mg} / \mathrm{dL}$ ). Pasien selanjutnya rawat inap dan mendapat albumin intravena dengan plasbumin 25\% 100 $\mathrm{ml}$ dalam dua kali pemberian. Pemberian albumin intravena dikombinasikan dengan pemberikan diuretik furosemid $40 \mathrm{mg}$ yang diberikan di tengah transfusi albumin. Pasca pemberian albumin pasien tampak edema berkurang, diuresis baik dan sesak berkurang. Sepuluh hari setelah rawat inap, pasien datang ke poliklinik masih dalam keadaan edema dengan ascites, sesak berkurang namun terdapat batuk. Tanda vital dalam batas normal kecuali tekanan darah berada pada persentil 99. Pasien membawa hasil pemeriksaan analisis cairan urine dengan hasil proteinuria $(+3)$, silinder leukosit $6-8 / \mathrm{lpb}$, sedimen eritrosit $0-1 / \mathrm{lpb}$, $\mathrm{pH}$ urine 7,5 dan berat jenis urin 1,030.

\section{Metode penelusuran}

Prosedur pencarian literatur untuk menjawab masalah klinis di atas adalah dengan menelusuri pustaka secara online dengan menggunakan instrumen pencari Pubmed, Cochrane, dan Proquest dengan kata kunci: "children", "nephrotic syndrome", "edema", "bypoalbuminemia", "albumin" dan "furosemid". Batasan yang digunakan adalah studi yang dilakukan pada manusia, publikasi bahasa Inggris, dan dipublikasikan antara Januari 2009 hingga Desember 2015. Penelusuran lebih lanjut secara manual pada daftar pustaka yang relevan. Pada akhir penelusuran ditemukan 8 uji klinis acak terkontrol, namun hanya 4 artikel yang berhasil didapatkan. Level of evidence ditentukan berdasarkan klasifikasi yang dikeluarkan oleh Oxford Centre for Evidence-based Medicine.

\section{Hasil penelusuran literatur}

Penelusuran artikel pada makalah ini menemukan empat artikel yang relevan terhadap pertanyaan klinis. Keempat artikel tersebut adalah penelitian oleh Kapur $\mathrm{dkk}^{6}$ yang merupakan suatu kohort prospektif, penelitian Dharmaraj $\mathrm{dkk}^{7}$ dan Ghafari $\mathrm{dkk}^{8}$ yang merupakan penelitian uji klinis, serta penelitian Duffy $\mathrm{dkk}^{9}$ yang merupakan suatu telaah sistematik.

\section{Uji klinis acak tersamar (Level of evidence I)}

1. Studi uji klinis oleh Ghafari $\mathrm{dkk}^{8}$ dilakukan terhadap 10 pasien anak $\mathrm{SN}$ dengan fungsi 
ginjal yang normal, dengan perlakuan pemberian albumin saja, furosemid saja atau kombinasi albumin-furosemid. Volume urin rata-rata setelah pemberian albumin saja, furosemide saja dan kombinasi adalah $742 \mathrm{~mL}$ $(\mathrm{SD}=528), 1707 \mathrm{~mL}(\mathrm{SD}=745)$ dan $2175 \mathrm{~mL}$ $(\mathrm{SD}=971)$, berturut-turut $(\mathrm{p}=0,015)$; ekskresi fraksi natrium adalah $1,96(\mathrm{SD}=0,251), 3,18$ $(\mathrm{SD}=0,25)$, dan $4,77(\mathrm{SD}=8,45)$, berturutturut $(\mathrm{p}=0,000)$; kadar natrium dalam urin 24 jam adalah 18,3 (SD=6,68), 208,4 (SD $=5,27)$ dan $206(\mathrm{SD}=8,45)$, berturut-turut; sedangkan glomerular filtration rate (GFR) adalah 104,5; 96,6; dan 106,6 ( $\mathrm{p}=0,021)$, berturut-turut pada 3 kelompok. Luaran dari penelitian tersebut menunjukkan bahwa urine output dan ekskresi natrium pada 24 jam menunjukkan peningkatan pada pemberian kombinasi dibandingkan dengan hanya pemberian furosemid saja.

\section{Sistematik review}

Pada tahun 2015, Duffy dkk dkelakukan $^{9}$ telaah sistematik terhadap 10 penelitian tentang penggunaan albumin dan furosemid pada pasien anak dan dewasa yang mengalami sindrom nefrotik dengan edema. Dalam kajiannya terhadap berbagai uji klinis, penggunaan albumin dan furosemid untuk mengatasi edema pada pasien $\mathrm{SN}$, didapatkan berbagai variasi rekomendasi sehingga belum ada rekomendasi definitif. Sebagian besar penelitian yang ditelaah menyimpulkan bahwa pasien nefrotik memenuhi kriteria resistensi diuretik, yaitu kegagalan respon terhadap dosis maksimum diuretik intravena (tunggal) atau kombinasi diuretik, sehingga penggunaan albumin adalah pilihan pengobatan yang potensial. Namun demikian, heterogenitas dari seluruh penelitian yang ditelaah, parameter pemantauan dan pemberian intervensi yang berbeda pada setiap penelitian yang ditelaah serta tidak terdapatnya cukup bukti yang menilai bahaya yang disebabkan oleh loop diuretic pada pasien SN dengan edema, ${ }^{10}$ yang pada akhirnya belum berhasil mengungkap mekanisme terapi kombinasi furosemid dan diuretik, dan menyarankan pemberian terapi didasarkan pada kondisi klinis per individu.
Saran dari telaah sistematik ini adalah dilakukannya penelitian uji klinis dalam skala besar pada pasien dengan resisten diuretik sehingga terdapat rekomendasi berbasis bukti terhadap penggunaan albumin dan furosemid.

\section{Studi kohort prospektif (level of evidence II)}

1. Studi oleh Dharmaraj $\mathrm{dkk}^{7}$ melakkan evaluasi 16 anak sindrom nefrotik dengan edema refrakter dalam suatu randomized cross-over. Diuresis dan natriuresis diukur setelah pemberian furosemid saja (8 pasien) dengan dosis infus $0,3 \mathrm{mg} / \mathrm{kg} / \mathrm{jam}$ selama 24 jam atau terapi kombinasi dengan albumin $1 \mathrm{~g} / \mathrm{kg}$ yang diberikan selama 4 jam dengan furosemid $0,3 \mathrm{mg} / \mathrm{kg} / \mathrm{jam}$ selama $24 \mathrm{jam}$ (8 pasien). Hasil penelitian menunjukkan efek positif jangka pendek (24 jam) pada mereka yang mendapatkan terapi kombinasi dalam hal diuresis dan natriureuris. Mekanisme yang dianggap mendasari hasil penelitian ini adalah peningkatan transport furosemid ke tubulus renalis akibat pemberian albumin dan bukan karena volume ekspansi intavaskular. Penelitian ini juga mendapatkan bahwa terjadi potensiasi kerja furosemid yang diberikan secara drip secara terus menerus dalam 24 jam setelah pemberian albumin. Namun demikian, terdapat keterbatasan penelitian antara lain tidak ditentukannya volume plasma pasien sejak awal penelitian, tidak dapat diklasifikasikannya status pasien ke dalam kondisi hipervolumik, euvolemik ataupun hipervolemik karena pasien yang dilibatkan sebelumnya telah mendapat diuretik rumatan, tidak diketahuinya perubahan hemodinamik renal pada pasien selama penelitian, serta tidak mengukur parameter farmakokinetik furosemid selama penelitian.

2. Penelitian kohort prospektif oleh Kapur $\mathrm{dkk}^{6}$ bertujuan mengevaluasi pemberian furosemid saja terhadap pasien $\mathrm{SN}$ yang mengalami edema berat. Penelitian ini berdasarkan pada hipotesis bahwa edema pada pasien anak dengan SN berhubungan dengan volume kontraksi dan volume ekspansi sehingga pemberian albumin intravena diharapkan dapat memperbaiki volume kontraksi pada 
pasien. Penelitian ini dilakukan pada pasien SN anak di Rumah Sakit Michigan selama dua fase, dimana jumlah pasien pada fase pertama dan kedua berbeda. Volume kontraksi diukur berdasar fraksi ekskresi sodium $(\mathrm{FeNa})<1 \%$ setelah pemberian albumin dan furosemid, sedangkan volume ekspansi diukur setelah pemberian furosemid IV dan spironolakton oral. Hasil penelitian menunjukkan bahwa pada kelompok yang mendapat terapi albumin dan furosemid memiliki kadar ureum serum, rasio ureum/kreatinin, osmolalitas urin yang lebih tinggi serta kadar $\mathrm{FeNa}$ dan natrium urin yang lebih rendah jika dibandingkan dengan kelompok pasien yang hanya diberikan diuretik saja. Hasil temuan ini didapatkan baik pada fase satu, maupun fase dua penelitian. Sehingga dapat ditarik kesimpulan dari bahwa penggunaan diuretik saja pada pasien anak dengan SN yang mengalami edema berat menunjukkan efektivitas yang baik, dalam hal lamanya rawat inap ( $\mathrm{p} 0,29)$ dan penurunan berat badan ( $\mathrm{p}$ $0,13)$.

Penelitian oleh Ghafari ${ }^{8}$ dan Dharmaraj ${ }^{7}$ menunjukkan efek yang menguntungkan dari pemberian albumin dan atau terapi kombinasi albumin dengan furosemid. Namun, laporan penelitian Kapur $\mathrm{dkk}^{6}$ sebelumnya tidak menunjukkan efek yang menguntungkan dari kombinasi albumin furosemid dibandingkan hanya dengan pemberian diuretik. Dengan demikian, penggunaan albumin dan furosemid masih tetap menjadi pilihan terapi yang kontroversial dalam tata laksana edema pada pasien dengan SN karena terdapat variabilitas dalam kriteria inklusi penelitian, desain eksperimental, dan luaran klinis.

\section{Pembahasan}

Sindrom nefrotik selalu berhubungan dengan retensi sodium di ginjal, dan hal ini pada akhirnya menyebabkan ekspansi asimetris dari jaringan interstitial. Saat ini diketahui konsep "underfill" atau "overfill" sebagai dasar terjadinya edema pada pasien SN. Namun demikian, peradangan interstitial adalah stimulus yang utama untuk terjadinya edema pada pasien. Patofisiologi SN melibatkan perubahan sifat intrinsik permeabilitas kapiler endotel sebagai pengendali asimetri volume ekspansi, perubahan barrier filtrasi glomerulus yang menyebabkan hipoalbuminemia dan proteinuria, serta aktivasi $\mathrm{Na}, \mathrm{K}$, ATPase pada distal nefron bertanggung jawab terhadap terjadinya retensi sodium di ginjal. Hubungan antara elemen-elemen ini belum dapat sepenuhnya dijelaskan tetapi mereka membantu untuk menjelaskan mekanisme edema pada pasien SN. Selain itu, penurunan tekanan onkotik plasma juga berperan penting dalam terjadinya edema pada SN. Diuretik dianggap sebagai dasar dari pengobatan untuk edema di SN karena mencegah retensi sodium ginjal. Namun, umumnya pasien $\mathrm{SN}$ akan ditatalaksana sesuai dengan manifestasi gejala per individu. ${ }^{3,11}$

Furosemid merupakan loop diuretic yang bekerja secara reversibel dengan melekat pada situs pengikat klorida kotransporter $\mathrm{Na}^{+} \mathrm{Cl}^{-} \mathrm{K}^{+}$di membran sel luminal pada segmen tebal ansa henle. Kotransporter ini bertanggung jawab untuk transpor natrium dari saluran kemih ke dalam sel tubulus melalui perbedaan konsentrasi. Efek utama penutupan kotransporter ini adalah mengurangi reabsorbsi sodium sebanyak 20$30 \%$, sehingga akhirnya terjadi diuresis. Furosemid juga berperan sebagai penghambat reabsorbsi natrium pada tubulus proksimal melalui blokade karbonik anhidrase. ${ }^{12}$

Awitan kerja furosemid intravena adalah 5 menit dengan efek puncak dalam waktu 30 menit dan durasi kerja 2-6 jam. Respons yang lebih lama tampak pada bayi prematur atau pada bayi setelah operasi jantung dengan onset 1 jam dan efek puncak dalam waktu 3 jam dan durasi kerja selama 6 jam. Pemberian furosemide intravena jauh lebih cepat awitan kerjanya dibanding pemberian secara oral, berkenaan dengan absorpsi di saluran cerna. ${ }^{12}$

Furosemid dapat digunakan untuk edema paru, gagal jantung kongestif, serta penyakit ginjal. Efek yang tidak diharapkan dari furosemid adalah gangguan elektrolit, hipovolemia dan hipotensi, tinitus hingga ketulian. Efek samping furosemid adalah gangguan saluran cerna, pankreatitis, ensefalopati hepatik, hipotensi postural, hiperglikemia, retensio urin, gangguan elektrolit (hiponatremia, hipokalemia), peningkatan ekskresi kalsium, nefrolitiasis, hipokloremia, hipomagnesemia, alkalosis metabolik, depresi sumsum tulang, hiperurisemia, gangguan penglihatan, ruam dan fotosensitivitas. ${ }^{13}$

Pada kasus ini didapatkan anak laki usia 17 
tahun 10 bulan, berat badan $90 \mathrm{~kg}$ dengan sindrom nefrotik resisten yang datang pasien dalam keadaan edema anasarka, status respirasi dan hemodinamik stabil, dari pemeriksaan penunjang darah dalam batas normal kecuali kadar albumin serum menunjukkan hipoalbuminemia (albumin 1,56 mg/dL). Pemberian albumin intravena pada pasien sebesar $1 \mathrm{~g} / \mathrm{kg} /$ kali dikombinasikan dengan pemberikan diuretik furosemid $40 \mathrm{mg}(0,5 \mathrm{mg} / \mathrm{kg})$ secara bolus dan diberikan di tengah transfusi albumin. Pasca pemberian albumin pasien masih tampak edema, sesak berkurang, selanjutnya sepuluh hari setelah rawat inap di IGD, pasien datang ke poliklinik masih dalam keadaan edema dengan ascites, sesak berkurang namun terdapat batuk-batuk.

Pasien mengalami edema karena hipoalbuminemia akibat proteinuria yang berat sehingga tekanan onkotik kapiler rendah dan terjadilah penurunan volume sirkulasi. Teori "underfill” ini kemungkinan besar mendasari terjadinya reabsorbsi natrium dan air sebagai kompensasi ginjal dari penurunan tekanan onkotik, karena saat itu fungsi ginjal masih dinilai baik berdasar penghitungan laju filtrasi glomerulus $98 \mathrm{~mL} /$ menit $/ 1,73 \mathrm{~m}^{2}$. Setelah pemberian kombinasi terapi edema tersebut, terdapat perbaikan dalam hal diuresis pada 24 jam pertama, namun berat badan pasien tidak berkurang, klinis lain sesak berkurang.

Penggunaan albumin dan furosemid pada anak yang edema karena sindrom nefrotik tidak menunjukkan perbaikan dalam hal natriuresis dan diuresis yang sifatnya permanen, dan hal ini secara statistik tidak bermakna. Salah satu penelitian bahkan menunjukkan bahwa pemberian furosemid saja dapat memberikan efek positif terhadap pasien SN dengan edema berat. ${ }^{6}$ Akan tetapi, penelitian yang mendukung pemberian furosemid tunggal pada SN dengan hipoalbuminemia dan edema tersebut masih dalam level of evidence 3 dengan jumlah subyek penelitian kecil. Walaupun Ghafari ${ }^{9}$ dan Dharmaraj ${ }^{8}$ berhasil menunjukkan adanya perbaikan natriuresis dan diuresis pada pemberian kombinasi albumin dan furosemid dibanding pemberian furosemid saja, efek tersebut hanya terjadi dalam waktu yang sementara dan tidak berlanjut memberikan efek perbaikan yang diharapkan. Kedua penelitian tersebut juga termasuk kedalam telaah sistematik Duffy ${ }^{11}$ yang pada akhirnya berkesimpulan bahwa kombinasi furosemid dan albumin tidak disarankan untuk diberikan secara rutin pada pasien SN dengan edema dan hipoalbuminemia. Belum terdapat penelitian saat ini yang dapat menjelaskan dengan rinci mengenai mekanisme diuretik albumin. Pemberian albumin dan furosemid disarankan untuk pasien SN dengan edema dengan kondisi tertentu, penilaian klinis kasus per kasus adalah mutlak, dan pemberian kombinasi terapi ini harus dengan perhatian khusus (with cautions).

\section{Kesimpulan}

Pemberian albumin dan furosemid bukan merupakan prosedur rutin pada setiap pasien SN dengan edema dan hipoalbuminemia. Secara statistik, efek diuretik dan natriuretik dari terapi kombinasi ini masih dianggap tidak bermakna, mekanisme diuretik albumin belum dapat dijelaskan dari perspektif patofisiologis, dan pemberian kombinasi albumin furosemid harus dengan pertimbangan dan perhatian khusus.

\section{Saran}

Penggunaan albumin dan furosemid dapat diberikan pada pasien dengan sindrom nefrotik dengan edema. Pemberiannya bukan merupakan prosedur rutin dan harus disarankan dengan pertimbangan serta perhatian khusus. Perlu dilakukan penelitian uji klinis dalam skala besar pada pasien dengan resisten diuretik sehingga terdapat rekomendasi berbasis bukti terhadap penggunaan albumin dan furosemid.

\section{Daftar pustaka}

1. Fliser D, Zurbruggen I, Mutschler E, Bischoff I, Nussberger J, Franek E, dkk. Coadministration of albumin and furosemid in patients with the nephrotic syndrome. Kidney Int 1999; 55: 629-34.

2. Sjostrom PA, Odlind BG, Beermann BA, Karlberg BE. Pharmacokinetics and effects of frusemide in patients with the nephrotic syndrome. Eur J Clin Pharmacol 1989; 37: 173-80.

3. Ichikawa I, Rennke HG, Hoyer JR, Badr KF, Schor N, Troy $\mathrm{JL}$, dkk. Role for intrarenal mechanisms in the impaired salt excretion of experimental nephrotic syndrome. J Clin Invest 1983;71:91-103.

4. Alderson P, Bunn F, Li WPA, Li L, Blackhall K, Roberts I, dkk. Human albumin solution for resuscitation and volume expansion in critically ill patients. Cochrane Database of Systematic Reviews 2011, Issue 10. [DOI: 10.1002/14651858. 
CD001208.pub4]

5. Oxford Centre of Evidence-Based Medicine 2011 Levels of Evidence. Diakses tanggal 3 April 2015.Diunduh dari: http:// www.ebcm.net/index.aspx? $0=5653$.

6. Kapur G, Valentini RP, Imam AA, Mattoo TK. Treatment of severe edema in children with nephrotic syndrome with diuretics alone - a prospective study. Clin J Am Soc Nephrol 2009;4:907-13.

7. Dharmaraj R, Hari P, Bagga A. Randomized cross-over trial comparing albumin and frusemide infusions in nephrotic syndrome. Pediatr Nephrol 2009;24:775-82.

8. Ghafari A, Mehdizadeh A, Alavi-Darazam I. Co-administration of albumin-furosemid in patients with the nephrotic syndrome. Saudi J Kidney Dis. Transplant 2011;22:471-5.

9. Duffy M, Jain S, Harrell N, Kothari N, Reddi AS. Albumin and furosemid combination for management of edema in nephrotic syndrome: a review of clinical studies. Cells 2015;4:622-30.

10. Brown EA, Markandu N, Sahnella GA, Jones BE, MacGregor GA. Sodium retention in nephrotic syndrome is due to an intrarenal defect: evidence from steroid-induced remission. Nephron 1985;39:290-5.

11. Doucet A, Favre G, Deschenes G. Molecular mechanism of edema formation in nephrotic syndrome: therapeutic implications. Pediatr Nephrol 2007; 22: 1983-90.

12. Buck ML. Furosemid: a review of ots use in infants and children. [disitasi tanggal 20 April 2015]. Diunduh dari: http:// www.medscape.com/viewarticle/712273.

13. Pediatric formulary committee. British National Formulary for children. London: Pharmaceutical Press;2014. h.77-8 